\title{
Development of Learning Material Based on Problem Based Learning to Increase Mathematical Connection Ability and Self-Esteem Students of SMP Negeri 1 Panai Tengah
}

\author{
Yacub Sitorus Hasratuddin Sahat Saragih \\ State University of Medan (UNIMED), Jl. Willem Iskandar Psr. V, Medan 20221, Indonesia
}

\begin{abstract}
This research aim to analysis: (1) the increasing of students' mathematical connection ability by using learning material based on problem based learning that has been developed, (2) the increasing of students' self-esteem by using learning material based on problem based learning that has been developed, (3) the quality of learning material developed based on problem based learning and (4) the students' mistake in completing the mathematical connection ability test on the comparison material. The development of learning based on problem based learning by using the 4-D development model. The stage of this research includes define, design, develop, and disseminate. The subjects of this research were students of class VII ${ }^{-1}$ and $\mathrm{VII}^{-2}$ SMP Negeri 1 Panai Tengah. From the results of trial I and trial II were obtained: (1) there was an increase in students' mathematical connection ability on posttest trials I and trials II of 5 point, (2) there was an increase in students' self esteem on posttest trials I and trials II of 0,10 point, (3) according to the expert, the validity of learning material is valid, the practicality of the learning material has fulfilled the practical criteria that have reviewed from: a) the validator stated the learning materials can be used with a little revisions; b) the result of observation of learning material has been done as said good, and the effectiveness of learning material has fulfilled the effective criteria in terms of: a) the mastery of students learning in classical; b) limits of tolerance that have been established on students' active activity; c) students' responses is positive to the components of learning materials and learning activities, and (4) the type of error that is often done by students in completing a mathematical connection ability test were mathematical error aspects of the transformation of 33,33\%.
\end{abstract}

Keywords: Learning Materials, 4-D Development Model, Problem Based Learning, Mathematical Connection Abilities, and Self-Esteem

DOI: $10.7176 / \mathrm{JEP} / 10-36-07$

Publication date: December $31^{\text {st }} 2019$

\section{INTRODUCTION}

An education is said to be of quality if the educational processes can produce individuals or human resources that benefit society and nation development. Given that mathematics is one of science that underlies the progress of science and technology (science and technology), so that mathematics is seen as a science that is structured and integrated, the science of patterns and relationships, the science of how to think to understand the world around. In learning mathematics, students get the opportunity to develop systematic, logical and critical thinking in communicating ideas or solving of a mathematical problem encountered.

According to the Ministry of National Education (Depdiknas : 2006 ) states there are several indicators that need to be developed in learning mathematics, such as mathematical understanding, problem solving, and reasoning and communication. The ability of mathematical connection is one of the important skills in learning mathematics, such as if the connection process is well established then it can build an understanding of mathematical ideas and make it more easily understand.

In studying mathematics, students are expected to achieve the objectives of mathematics learning as formulated by the National Council of Teachers of Mathematics (2000) five standard mathematical learning process: Problem solving, reasoning and proof, communication, representations and connections. While the 5 standard content in the mathematical standards of numbers and operations, problem solving, geometry, measurement, opportunities and analysis.

One of the objectives of study the mathematics NCTM mentions on standard content and process standards is problem solving. Sinaga (1999: 10) say that "problem-solving ability is the ability or strategic competence shown by students in understanding, choosing approach and solving strategies and solving models to solve problems ". While Mullis (2000) suggests that "learning is more emphasis on reasoning activities and problem solving is closely related to the achievement of high student achievement". Even Posamentier and Stepelmen (1990) put problem solving as the first sequence of 12 essential mathematical components and learning to solve problems is a principal reason for studying mathematics. While PISA (Program for International Student Assessment) and Bloom's Taxonomy put on problem solving skills at High Order Thinking level which is at level 4 or C 4. PISA is an international study to test student literacy achievement of reading, math, and science.

Facts on the ground, students mathematical connection ability are still low. The hope of the formation of 
quality human resources, so far has not been realized. The Global Talent Competitiveness Index (GTCI) report in 2017 shows that Indonesia's global talent competitiveness index ranks 90th among 118 countries in the Asia Pacific region (Lanvin and Evans, 2016). Indonesia received a score of 36.81, which is very low compared to the highest score obtained by Switzerland, which obtained a score of 74.55. Indonesia's position is much lower than Singapore and Malaysia which are in the 2nd and 28th positions. The scores of the two countries are 74.09 and 56.22. The index is measured based on the ability of a country to compete in scoring talent and human resource capabilities. This has shown the low quality of Indonesian students' mathematical knowledge at the international level. The facts in SMP Negeri 1 Panai Tengah about students 'mathematical connection ability are seen from the questions tested in class VII students' answers. This is confirmed by research Siregar \& Surya (2017) said that mathematical connection ability is in accordance with the level of basic ability of mathematics that is for the student who are in the group on the student's connection ability is high (86\%), the student are in the middle group the ability of students connection is moderate (74\%), and the students which is in the group below the ability of mathematical connections are very low (32\%).

In addition to the importance of problem solving skills in mathematics, as well as attitudes that must be possessed by students because in the curriculum of 2013, learning objectives cover the development of the sphere of attitude, knowledge, and skills. One of the attitudes students must have is self esteem of learning because it is closely related to mathematical connection.

The importance of learning independence for students is conveyed by the results of Darr and Fisher's (2004) study which reported that "independent learning ability correlates highly with student learning success". Students with high success levels make higher goals, use more effort, survive longer when facing difficulties and will most likely use independent learning strategies (Bandura, 1997). The effort of most students in finding solutions is through self-regulatory activity, in this case students' independence learns how students analyze problems, monitor the completion process, and evaluate the results (De Corte, 1996).

One of the factors that can improve students' mathematical connection ability and self-esteem is the use of innovative and student-centered learning models. However, the use of innovative and teacher-centered learning models has not yet been done in SMP Negeri 1 Panai Tengah. This is evident from interviews with math teachers at SMP Negeri 1 Panai Tengah. They say that teachers often use teacher-centered and teacher-centered learning models. Aside from the interview, the Lesson Plans (RPP) used by teachers also shows that teachers use teachercentered and teacher-centered learning models. Therefore, the learning model used in this research is problem based learning (PBM). "Using a problem-based learning model will help students to develop thinking skills, problem-solving skills, and learn the roles of adults to become independent learners" (Arends, 2008).

To support the implementation of learning with problem-based learning model, learning tools are needed that facilitate the planning, implementation and evaluation of learning. Learning tool is a collection of learning resources that enable students and teachers to do learning activities. Learning tools consist of syllabus, Learning Implementation Plan (RPP), student book, teacher book, student activity sheet, and test of learning result. The importance of the use of learning tools by teachers is mentioned in Law No. 14 of 2005 on teachers and lecturers that "in carrying out professional duties, teachers are obliged to plan lessons, carry out quality learning processes, and assess and evaluate learning outcomes". It is also available in the 2013 curriculum that a teacher must be able to utilize the learning resources that have been provided, able to develop media or other learning resources.

Learning device used by teachers have not been directed to teaching high-order thinking in this case the ability to solve mathematical problems and the independence of student learning, the need to develop learning tools that teaching mathematical problem-solving ability and student learning independence. In addition, the tools teachers use do not relate to one another and are never validated and tested before use. This is evident from the teacher's admission that they say "learning tools are made only to fulfill obligations when there is supervision from the leadership and that is made by others".

Based on the above conditions and expectations, in this study will be developed learning tools in the form of Learning Implementation Plan (RPP), Student Book (BS), Student Activity Sheet (SAS), Mathematical Connections Tests and self esteem questionnaire by submitting a study with the title "The development of learning tools based on problem-based learning to improve students' mathematical connections ability and self esteem.

\section{LITERATURE}

\subsection{Mathematical Connection Abilities}

According to Ruspiani (2000) the ability of mathematical connections is the ability of students to associate mathematical concepts both between mathematical concepts and associate mathematical concepts with other fields of science (outside mathematics). This understanding implies that mathematical connections allow students to see how a mathematical concept can help him understand other concepts. In mathematics every concept is related to other concepts. Neither with others, for example between the proposition and the proposition, between theory and theory, between topic and topic, or between branches of mathematics with other 
branches of mathematics.

Ruspiani (2000) states that if a topic is given separately then learning will lose one very valuable moment in an effort to improve student achievement in learning mathematics in general. Without mathematical connection ability, students will have difficulty learning mathematics.

According Kusuma (2011) that "the mathematical connections ability is the ability of a person to show the internal and external relations of mathematics, which includes connections between mathematical topics, connections with other disciplines, and connections with everyday life". From the opinions of these experts, it can be concluded that the mathematical connection is the ability to link between topics in mathematics, associate mathematics with other sciences, and with everyday life.

The application in learning mathematical connections is arranged in relevant indicators, including as explained by Sumarmo (Agustina, 2011) as follows:

1) Looking for the relationship of various representations of concepts and procedures

2) Understand the relationship between mathematical topics

3) Using mathematics in other fields of study or everyday life

4) Understanding equivalent representations of concepts or procedures that are equally equivalent

5) Looking for the relationship of one procedure to another in an equivalent representation

6) Using connections between mathematical topics, and between mathematical topics with other topics.

Furthermore, Ritonga, Sinaga \& Siagian (2018) define mathematical connection capabilities as:

Mathematical connections are divided into three group: 1) aspects of connection between mathematics topics, 2) aspects of connection with other disciplines, and 3) aspects of connection with real word students (connection with daily life). Through mathematical connections it is expected that students' insight and thoughts will be more open, not just focused on the topic being studied, so as to foster a positive attitude towards math lessons.

\subsection{Students' Self-Esteem}

Self esteem is one part and personality of a person that is very important in everyday life. According to Coopersmith (in Kartikasari 2017) self esteem is an evaluation made by an individual and is usually related to self-esteem, this expresses an attitude of agreeing or disagreeing and showing the level at which the individual believes himself capable, important, successful and valuable .

In general, self esteem is an evaluative component and self-concept, broader self-representation so that it includes cognitive and behavioral aspects that are judgmental and affective. (Coetzee, 2005). According to Santrok (2003) Self-esteem is a comprehensive and self-evaluative dimension. Self esteem is also referred to as self-esteem or self-image. Roman (Coetzee, 2005) describes Self-esteem as one's self-confidence, knowing what is best for oneself and how to do it. Clemens and Bean (2014) also stated that self esteem is a person's judgment about himself as a person who is valuable and should.

According to Maslow (Aiwisol, 2009) self esteem is a human need that requires fulfillment or satisfaction to proceed to a higher level of need. The need for self esteem by Maslow is divided into two types namely $\mathrm{d}$ penghargaanñ awards and other people's awards. Maslow (in Alwisol, 2009) also argues that once a person feels loved and has a sense of belonging, they will develop the need for esteem. Furthermore, Kartikasari and Widjajanti (2017) define self esteem as: Self esteem is related to how students see themselves or individual assessments of their capabilities. Self esteem is the acceptance of individuals against her and that she can vote, deserve to be appreciated, deserves to be successful and valuable.

Based on the description above, it can be concluded that self-esteem is an individual's assessment of his ability, success, usefulness and goodness. Someone who has high self esteem, more appreciates himself or sees himself as something of value and can recognize his mistakes, but still values the values that exist in him.

\subsection{Problem Based Learning}

Problem-based learning model has been known since the time of John Dewey and developed for the first time by Howard Barrows in the early 1970s. Problem-based learning is a learning approach that uses the problem as a starting point for learning. The problems that can be used as a means of learning are problems that meet the realworld context, which is familiar with the daily life of the students. Through these contextual problems the students rediscover the knowledge of essential concepts and ideas from the subject matter and build them into the cognitive structure.

Arends (2008: 56) said that the problem-based learning model is a learning model where students work on authentic issues with the intent to develop their own knowledge, develop inquiry and higher-order thinking, develop self-reliance and self-confidence. Nurhadi (2003: 109) said that "Problem Based Learning (PBL) is a learning model that uses real-world problems as a context to learn about critical thinking and problem-solving skills, and acquire essential knowledge and concepts from subjects". University of Southern California (2001) that problem-based learning is an inquiry-based approach with students or students gaining experience as investigators and teachers functioning as thinking trainers. 
From some opinions above, it can be concluded that problem-based learning is one model of learning, where students are faced with real contextual problems with daily life to gain knowledge so that it can solve the problem based on his knowledge.

\section{RESEARCH METHOD}

This research is a development research using 4-D development model Thiagarajan, Semmel, and Semmel [23] in 1974 consisting of 4 stages, define, design, develop, and disseminate.

\subsection{Subjects and Research Objects}

Subjects in this study are students of class $\mathrm{VII}^{-1}$ and VII-2 SMP Negeri 1 Panai Tengah academic year 2019/2020, while the object in this study is learning devices developed by using problem based learning on fractional material. Learning devices developed are Learning Implementation Plan, Teacher's Book, Student's Book, Student's Worksheet, Mathematical Connection Ability test and questionnaire students' self esteem. Development of learning devices using the Thiagarajan 4-D development model. However, the disseminate stages are not performed.

\subsection{Instruments and Data Analysis Techniques}

Instruments in this study using tests, questionnaires and observation sheets. For more details are presented in Table 1.

Table 1 Data Analysis Instruments and Techniques

\begin{tabular}{|l|l|l|l|}
\hline \multicolumn{1}{|c|}{ Rated Aspect } & Instruments & \multicolumn{1}{|c|}{ The Observed Data } & Respondents \\
\hline $\begin{array}{l}\text { Validity of problem } \\
\text { based learning tools }\end{array}$ & $\begin{array}{l}\text { Validation } \\
\text { Sheet }\end{array}$ & $\begin{array}{l}\text { Learning Implementation Plan, Teacher's Book, Expert/Specialist } \\
\text { Student's Book, Student's Worksheet, } \\
\text { Mathematical Connection Ability Test, Self- } \\
\text { Esteem }\end{array}$ & Observer \\
\hline $\begin{array}{l}\text { Practicality of } \\
\text { problem } \\
\text { learning tools based }\end{array}$ & $\begin{array}{l}\text { Observation } \\
\text { Sheet }\end{array}$ & Learning Devices Implementation & Student \\
\hline $\begin{array}{l}\text { Effectiveness of } \\
\text { problem } \\
\text { learning tools }\end{array}$ & Test & Mathematical Connection Ability Test & Observer \\
\cline { 2 - 5 } & $\begin{array}{l}\text { Observation } \\
\text { Sheet }\end{array}$ & Teacher's Ability to Manage Learning & Student \\
\cline { 2 - 5 } & Questionnaire & Student's response & \multicolumn{2}{l}{} \\
\hline
\end{tabular}

\subsubsection{Validity of Learning Device Based on Problem Based Learning}

Learning tools developed based on Problem Based Learning are validated by five expert. Criteria of learning tools based on Problem Based Learning are as follows:

Table 2 Level of Criteria Validity

\begin{tabular}{|c|c|}
\hline Va or value of average total & Validity of Criteria \\
\hline $1 \leq \mathrm{Va}<2$ & Invalid \\
\hline $2 \leq \mathrm{Va}<3$ & Less Valid \\
\hline $3 \leq \mathrm{Va}<4$ & Valid Enough \\
\hline $4 \leq \mathrm{Va}<5$ & Valid \\
\hline $\mathrm{Va}=5$ & Very Valid \\
\hline
\end{tabular}

Annotation: $\mathrm{Va}$ is the value of determining the level of prevalence and learning devices using Problem Based Learning.

Meanwhile, to calculate the validity and Ability of Mathematical Connection test and self-esteem questionnaires used product moment correlation formula that is:

$$
r_{x y}=\frac{n \sum X Y=\left(\sum X\right)\left(\sum Y\right)}{\sqrt{\left.\left\{n \sum X^{2}-\left(\sum X\right)^{2}\right\} n \sum Y^{2}-\left(\sum Y\right)^{2}\right\}}}
$$

Annotation:
$\mathrm{X}$ : Score item
rxy: test validity coefficient
Y: The total score
$\mathrm{n}$ : many respondents who took the test

Determining the royalty coefficient of a form test description used the alpha formula as follows: 


$$
r_{11}=\left(\frac{n}{n-1}\right)\left(1-\frac{\sum \sigma_{1}^{2}}{\sigma_{1}^{2}}\right)
$$

Annotation:

r11 : test reliability coefficient

$\mathrm{n}$ : number of test items

$\Sigma \sigma i 2:$ the number of variance scores per test item

$\sigma i 2$ : total variance

\subsubsection{Practicality of Learning Device Based on Problem Based Learning}

The first of Analysis the practicality Problem Based Learning is to use the validation sheet, where all experts stated that the Problem Based Learning device can be used with "minor revision" or "no revision". As for seeing the enforce ability of the device used Problem Based Learning observation sheet improvement learning device. Criteria improvement learning device is as follows:

Very Low, If $0 \leq P<1$

Low, If $1 \leq P<2$

Enough, If $2 \leq P<3$

High, If $3 \leq P<4$

Very High, If $4 \leq P \leq 5$

Annotation:

$P$ is the average score

Problem Based Learning device is said to be practical or easy to implement if the enforce ability of the Problem Based Learning are in the category of high minimal.

\subsubsection{Effectiveness of Learning Devices Based on Problem Based Learning}

Complete Classical Ability of Mathematical Connection. The effectiveness of Problem Based Learning is based on student achievement in classical mastery learning. The criteria that states that students have been able to represent mathematically if there are $75 \%$ of students who follow the ability mathematical problem solving with a minimum value of 75 . Percentage can be calculated by the formula:

$$
\text { Persentage of Agreement }=\frac{\operatorname{Agrements}(A)}{\text { Disagreemnet }(D)+\operatorname{Agreements}(A)} \times 100 \%
$$

\subsubsection{Teacher's Ability to Manage Learning}

The activity of the teacher to manage the learning process is the ability to develop a familiar and positive learning atmosphere. The activity of determining the average score of the total aspects of the assessment of teachers' ability to manage learning adapts the steps Hobri developed by Suryaningsih [27] in 2014, with the following criteria: Criteria: Since the range of these scores is 0 to 5 , the length of the interval within this score range is 5 . To make the criteria of the effectiveness of the teacher's ability to manage the learning, this interval is subdivided into $5 \mathrm{sub}$ equal intervals:

Very low, if $0 \leq P<1$

Low, if $1 \leq P<2$

Simply, if $2 \leq P<3$

High, if $3 \leq P<4$

Very High, if $4 \leq P \leq 5$

\subsubsection{Student Response}

Questionnaire responses of students were analyzed by calculating the percentage of many students who responded positively to each of the categories asked in the questionnaire by using the following formula:

$$
\text { PRS }=\frac{\sum A}{\sum B} \times 100 \%
$$

Information :

PRS: Percentage of many students who respond positively to each of the categories asked

$\Sigma$ A: Proportion of students who choose

$\Sigma$ B: Number of students (respondents)

The criteria are set to say that students have a positive response to learning tools developed when the number of students who responded positively was greater than or equal to $80 \%$ of the many subjects studied for each trial by Sinaga [29] in 2007.

\subsubsection{Improved The Ability to Mathematical Connection Ability}

To calculate the improvement of students' mathematical connection ability after using mathematical learning devices developed based on Problem Based Learning determined by gain formula, that is: 


$$
\text { gain }=\frac{\text { posttest value }- \text { pretest value }}{\text { ideal value }- \text { pretest value }}
$$

With the following criteria:

Table 3 Gain value Category

\begin{tabular}{|l|l|}
\hline Gain Value & Category \\
\hline gain $<3.0$ & Low \\
\hline $3.0<$ gain $<7.0$ & Middle \\
\hline gain $>7.0$ & High \\
\hline
\end{tabular}

Improvement of Students' Self-Esteem To find out the scale of student's self esteem based on scores obtained students can use criteria that refer to the opinion of Prastini \& Retnowati [31] in 2014 as follows:

Table 4 Level of Mastery of Student Learning Independence

\begin{tabular}{|c|c|c|c|}
\hline \multirow{2}{*}{ No } & \multicolumn{2}{|c|}{ Conversion Value } & \multirow{2}{*}{ Category } \\
\cline { 2 - 3 } & Value & Alphabet & Very Good \\
\hline 1 & $76-100$ & A & Good \\
\hline 2 & $51-75$ & B & Enough \\
\hline 3 & $26-50$ & C & Not good \\
\hline 4 & $0-25$ & D & \\
\hline
\end{tabular}

\section{RESULT AND DISCUSSION OF RESEARCH}

After conducting the research, there are some findings found, namely; the validity, the practicality, and the effectiveness of teaching materials, improving students 'mathematical connection ability, and improving students' self-esteem.

\subsection{Material Validity Of Teaching Materials}

The validity of instructional materials is measured by the experts. Based on the results of expert materials analysis, learning devices based on problem based learning for both teachers' and students' books obtained the average value of total validity as shown in Table 5 .

Table 5. The Validation of RPP, SAS, Teacher's and Student's Books

\begin{tabular}{|c|c|c|c|c|c|c|c|c|c|}
\hline \multirow[b]{2}{*}{ Aspects } & \multicolumn{4}{|c|}{ Aspect Average( $\left(\mathbf{A}_{\mathbf{i}}\right)$} & \multicolumn{4}{|c|}{ Total $\left(\mathrm{V}_{0}\right)$} & \multirow{2}{*}{$\begin{array}{c}\text { Validity } \\
\text { Degree }\end{array}$} \\
\hline & RPP & SAS & $\begin{array}{c}\text { Teacher's } \\
\text { Book }\end{array}$ & $\begin{array}{c}\text { Student's } \\
\text { Book }\end{array}$ & RPP & SAS & $\begin{array}{c}\text { Teacher's } \\
\text { Book }\end{array}$ & $\begin{array}{c}\text { Student's } \\
\text { Book }\end{array}$ & \\
\hline Template & 4.30 & 4.40 & 4.33 & 4.45 & \multirow{4}{*}{4.21} & \multirow{4}{*}{4.27} & \multirow{4}{*}{4.26} & \multirow{4}{*}{4.29} & \multirow{4}{*}{ Valid } \\
\hline Language & 4.04 & 4.20 & 4.25 & 4.20 & & & & & \\
\hline Illustration & & & 4.06 & 4.16 & & & & & \\
\hline Content & 4.30 & 4.22 & 4.40 & 4.34 & & & & & \\
\hline
\end{tabular}

Based on Table 5 above, the average value of the total validity of learning devices based on problem based learning is at intervals: $4 \leq \mathrm{Va}<5$. It means that the development of learning devices based on problem based learning is valid..

\subsection{Practicality Of Instructional Materials}

The practicality of teaching materials based on development of learning devices based on problem based learning seen in 2 (two) aspects, namely: (1) expert / practical assessment of the developed teaching materials can be used with minor revision; (2) the results of observation of the implementation of teaching materials in the classroom is quite high category (teaching material is applicable). Based on the result of observation data analysis of learning devices based on problem based learning, the average value of observation of teaching materials implementation for each meeting in experiment I shown in Table 3.

Table 6. The Average of Observation of the Implementation of Material in Experiment I

\begin{tabular}{|c|c|c|c|c|c|c|}
\hline \multirow[t]{2}{*}{ The Average of All Experts } & \multicolumn{4}{|c|}{$\frac{\text { Meeting }}{\bar{P}_{2}}$} & \multirow{2}{*}{$\frac{\text { Total }}{\boldsymbol{P}_{3}}$} & \multirow[t]{2}{*}{ Note } \\
\hline & 1 & 2 & 3 & 4 & & \\
\hline EXPERIMENT 1 & 3.73 & 3.80 & 3.93 & 4.00 & 3.86 & High (Practical) \\
\hline
\end{tabular}

Based on Table 6 , the average of observers of teaching learning device is in the high category $(3 \leq \mathrm{P} \leq 4)$ with the interval: $4 \leq \mathrm{Va}<5$. Based on the criteria of implementation, it means that the development of learning devices based on problem based learning developed is categorized as practical. 


\subsection{The Effectiveness Of Instructional Materials}

The criteria for determining the effectiveness of learning devices based on problem based learning in Experiment I and II consisted of three indicators as discusses as follows:

\subsubsection{Completeness}

Based on the finding of research in experiment I and II, the results obtained the completion as in Table 7:

Table 7.The Grade of Classical Completion of Mathematical Reasoning Ability in Experiment I and

\begin{tabular}{|c|c|c|c|c|}
\hline \multirow{2}{*}{ Categories } & \multicolumn{3}{|c|}{ Mathematical Problem Solving Ability } \\
\cline { 2 - 5 } & \multicolumn{2}{|c|}{ The total of students } & \multicolumn{2}{c|}{ Percentage } \\
\cline { 2 - 5 } & Experiment I & Experiment II & Experiment I & Experiment II \\
\hline Complete & 23 & 27 & $71.87 \%$ & $90 \%$ \\
\hline Incomplete & 9 & 3 & $28.13 \%$ & $10 \%$ \\
\hline Total & 32 & 30 & $100 \%$ & $100 \%$ \\
\hline
\end{tabular}

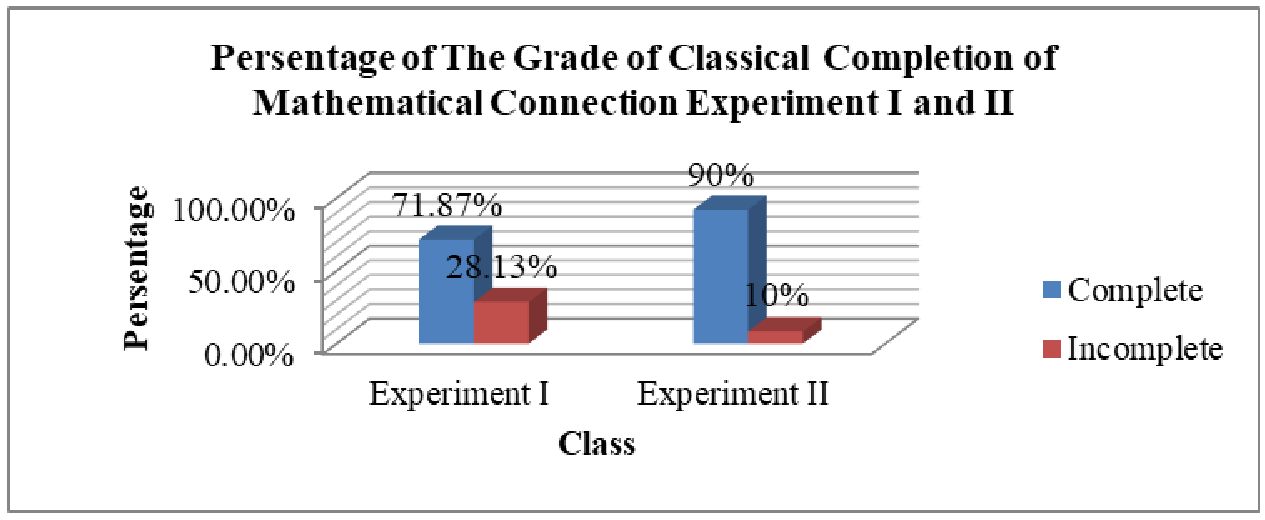

Picture 1: Persentage of The Grade Classical Complete of Students' Mathematical Problem Solving

Based on Table 4 and picture 1, it is showed that posttest result of mathematical connection ability in Experiment I test did not met the criteria of classical completeness achievement. In accordance with the students' learning completeness criteria in classical is at least $85 \%$ of students who follow the learning achieving $\geq 71$. Thus, the posttest result of mathematical connection ability in experiment II completely met the criteria of classical achievement. This is supported by Malasari, Nindiasari and Jaenudin (2017) state that the application of problem-based learning can improve mathematical connection skills. Besides being able to improve the ability of mathematical connections, the application of problem-based learning is also appropriate in developing students 'self-esteem, and the results of Syahputra and Surya's research (2017) show that the use of teaching materials can improve students' higher-order thinking skills.

\subsubsection{Students' Feedback}

Students' feedback criteria can be effective, if there are $80 \%$ research subjects showed positive feedback against component of developing teaching material. Based on the results of research on experiment I and II, students give positive feedback to the content of teaching materials developed. This is reinforced by Mawaddah's research (2015: 10) found that students show positive feedback for learning mathematics model with discovery learning and problem based learning.

\subsection{Improvement Of Mathematical Connection Ability}

To know the improvement of mathematical connection learning, the data obtained from experiment I and trial II were analyzed by comparing the mean score of students. The description of improving students' mathematical connection ability using learning devices based on problem based learning developed in experiment I and II shown visually in Table 8.

Table 8. Description of the Results of Mathematical Connection Ability

\begin{tabular}{|c|c|c|}
\hline Description & Experiment I & Experiment II \\
\hline Highest Score & 90 & 95 \\
\hline Lowest Score & 60 & 50 \\
\hline Average & 73.125 & 78.10 \\
\hline
\end{tabular}

Based on Table 8, the results of the improvement of students mathematical connection ability on experiment I and experiment II indicate that the average of students' mathematical connection ability on the result of posttest experiment I was 73.125 increased to 78.10 in experiment II.

Furthermore, a description of the enhancement of students' mathematical connection ability by using learning devices based on problem based learning on experiment I and II for each student's mathematical 
connection indicator can be shown in Table 9

Table 9. The Average of Student Mathematical Connection Ability for each indicator

\begin{tabular}{|l|c|c|c|}
\hline \multicolumn{1}{|c|}{ Indicators } & \multicolumn{2}{|c|}{ Mean for each indicator } \\
\cline { 2 - 4 } & $\begin{array}{c}\text { Experiment } \\
\text { I }\end{array}$ & $\begin{array}{c}\text { Experiment } \\
\text { II }\end{array}$ & Mean \\
\hline Applying Relationships between Math Topics & 3.44 & 3.60 & 0.16 \\
\hline $\begin{array}{l}\text { Applying the Relationship between Math Topics and Other Science } \\
\text { Discipline Topics }\end{array}$ & 3.10 & 3.30 & 0.20 \\
\hline Applying the Relationship between Mathematics and Everyday Life. & 2.50 & 2.70 & 0.20 \\
\hline
\end{tabular}

For more details can be seen in Figure 2

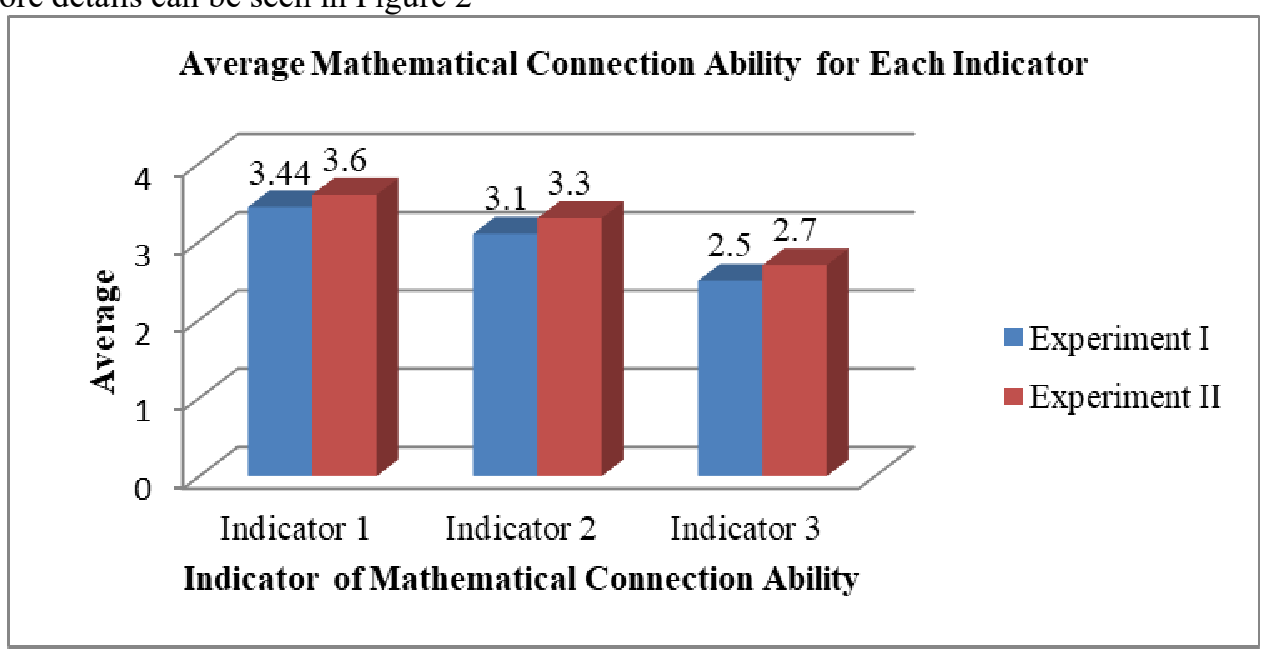

Picture 2: Average Mathematical Connection Ability for Each Indicator

Based on Table 9 and Ficture 2. above, it can be concluded that students' mathematical connection ability from experiment I to eksperiment II is seen from the average value of total and the average value of each indicator has increased through the application of learning devices based on problem-based learning developed. Increase in the average value of each of the highest indicators in indicator 3 because it is still resolving the problem while the indicators 1 and 2 slightly increased due to already been analyzed.

Then, Wijaya (2012: 32) The context in problem based learning is aimed at building or rediscovering a mathematical connection through the process of mathematical. The stages of connection is a part must be experienced by students in the process of developing mathematical connection in writing and also in the learning process with problem based learning.

\subsection{Improvement Students' Self Esteem}

Based on the results of experiment I and II, it is obtained the result of questionnaire of students' self esteem. This questionnaire is given at the end of each meeting which aims to see students' self esteem. Then obtained data from the results of questionnaire self esteem experiment I and II were analyzed to determine the improvement of students' self esteem by comparing the average score of students obtained from the questionnaire attitudes self esteem experiment I and II. The descriptions of improvement of students' self esteem after the application of developing problem based learning based material are shown in Table 10.

Table 10. The Mean of Self Esteem Students'

\begin{tabular}{|c|c|c|c|c|}
\hline \multirow{2}{*}{ No } & \multirow{2}{*}{ Indicators } & \multicolumn{2}{|c|}{ Mean for each indicator } & \multirow{2}{*}{ Mean } \\
\hline & & Experiment I & Experiment II & \\
\hline 1 & Accept Yourself & 27.78 & 27.97 & 0.09 \\
\hline 2 & Positive thinking & 27.44 & 27.88 & 0.44 \\
\hline 3 & Having Activities that Tend to Improve & 26.13 & 26.81 & 0.68 \\
\hline 4 & Active Around the Environment & 28.03 & 29.47 & 1.44 \\
\hline 5 & Believe in the capabilities you have & 28.16 & 29.09 & 0.99 \\
\hline 6 & Dare to take risks & 28.03 & 28.13 & 0.10 \\
\hline \multicolumn{2}{|r|}{ The mean of each indicator } & 2.75 & 2.82 & \\
\hline \multicolumn{4}{|c|}{ The mean of self esteem improvement from experiment I and II } & 0.07 \\
\hline
\end{tabular}

For more details can be seen in Ficture 3 


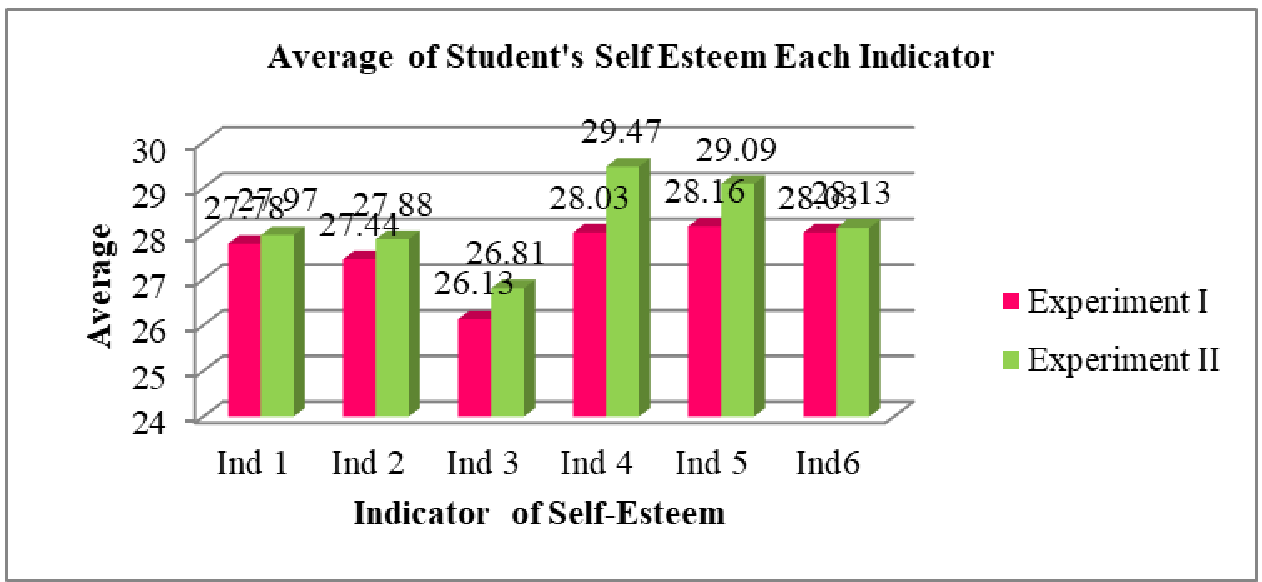

Ficture 3. Average of Student's Self Esteem For Each Indicator

Based on Table 10 and Figure 3 above can be seen that the average score of the highest indicator is in the indicator 4 that is Active Around the Environment and the lowest is indicator 3 that is Having Activities that Tend to Improve.. Then the level of mastery of student self esteem is seen from the increase of experiment I to experiment II, so it can be concluded that the average of the results of questionnaire student self-esteem increased from the results of experiment I to experiment II, namely the experiment I of 2.75 while on the test experiment II of 2.82 and increase by 0.07 . While the average score of each indicator also there is an increase from experiment I to experiment II. Each average score of each indicator on experiment I increases to experiment II

\section{CONCLUSION}

Based on discussion of the research, the conclusions are drawn as follows:

1. The learning devices developed has met the valid category with the average total validity of RPP of 4.21, the average teacher's book validity of 4.26 , the average student's book validity of 4.29 , and the average validity of SAS of 4.27 .

2. The learning devices developed have met the practical criteria reviewed from the expert's assessment of learning tools developed with minor revisions and without revisions, as well as interviews with some students saying that learning tools developed are easy to use.

3. The learning devices developed have met the effective criteria. Effective criteria are reviewed from the criteria of achievement of students 'learning mastery and the achievement of teachers' ability to manage learning.

a. Achievement of students' complete mastery in experiment I have 23 students complete $(71.87 \%)$ of 32 students, whereas in experiment II there are 27 students complete (90\%) of 30 students, so this criterion has been achieved.

b. Achievement of teachers' ability to manage learning in experiment I, the average of teacher ability to manage learning is 2.83 (good enough), while in trial II average is 3.37 (good), so this criterion has been reached.

4. Improved mathematical connection ability using problem-based learning tools seen from the average achievement of students' mathematical connection abilities in experiment I of 73.125 increased to 78.10 in experiment II.

5. Students' self-esteems increased from experiment I to experiment II using learning based on problem-based learning.

\section{REFERENCES}

Arends, I.R. 2008. Learning to Teach, Belajar untuk Mengajar. Edisi Ketujuh. Jilid Dua. Terjemahan oleh Soedjipto, Helly, P. dan Soedjipto, Sri, M. Yogyakarta: Pustaka Pelajar

Agustina, L. 2011. Peningkatan Kemampuan Pemecahan Masalah dan Koneksi Matematis Siswa SMP dengan Menggunakan Pembelajaran Berbasis Masalah. Tesis. Medan: PPs Unimed. tidak dipublikasikan

Arikunto. S. 2009. Dasar-Dasar Evaluasi Pendidian (edisi revisi), Jakarta: Bumi Aksara

Aiwisol, 2009. Psikologi Kepribadian (revisi edition). Malang: UMS Press

Bandura, A. 1997. Self Efficacy: The Exercise Of Control. New York: W.H. Ferman \& Company

Branca, N. A., 1980, 'Problem Solving as a Goal, Process, and Basic Skills', in S. Krulik and R. E. Reys (eds.), Problem Solving in School Mathematics, (pp. 3-8) National Council of Teachers of Mathematics: Virginia.

Cai, J. Kaiser, G. Perry, B. Ying, WN (Eds.). 2009. Effective mathematics teaching from teachers' perspectives : National and cross-national studies. Rotterdam: Sense Publisher. 
Campione, J.C.; Brown, A.L, and Connell, M.L. 1988. Metacognition: On the Importance of Understanding What You Are Doing. In Charles, R.I. and Silver, E.A. (Eds). The Teaching and Assessing Of Mathematical Problem Solving, Vol, 3. Reston, VA: NCTM.

Chamot, A.U, Barnhardt, S, Eldinary P.B \& Robbins, J. 2000. The Learning Strategies Handbook. New York, ISSN: 1550-6908

Coetzee, M. 2005. Employee Commitment. University of Proteria etd. http://upetd.up.ac.za/thesis/available/etd

Creswell, J.W. 2014. Research Design: Qualitative, Quantitative, and Mixed Methods Approach (4 ${ }^{\text {th }}$ ed). London: Sage Publication Ltd

Department of Education (1996). Educator Servis teaching \& Learning Curriculum Resources, Mathematics Curriculum Framework Achieving Mathematical Power Januari 1996.

De Corte, E. Verschaffel, L. Van Coillie, V. 1998. Influence of number size, problem structure and reesponse mode on children's solution of multiplication word problems (hlm. 197-216). Journal of Mathematical Behavior

Dick, W., Carey, L.,dan Carey, J.O. (2009). The Systematic Design of Instruction. New Jersey : Pearson

Freudenthal, H. 1973. Mathematics as an Educational Task. Dordrecht: Reidel Pub. Co

Goodman \& Smart. 1999. Emotional Intelligence. New York: Bantam Boks

Hudoyo, H. 1998. Pembelajaran Matematika Menurut Kontrutivisme. Malang : PPs. IKIP Malang

2003. Pengembangan Kurikulum dan Pembelajaran Matematika. (Common Text Book) Malang : FMIPA Universitas Malang/ IMSTEP

Ibrahim, M dan Nur, M. 2000. Pengajaran Berdasarkan Masalah. Surabaya: Unesa-University Press

Kartikasari, A., dan Widjajanti, D.B. 2017. The Effectivennes of Problem-Based Learning Approach Based on Multiple Intelligences in Terms Of Students' Achievement, Mathematical Connection Ability, and SelfEsteem. IOP Conf.Series: Journal of Physics: Conf. Series 812:1-6)

Kusuma, D.A. 2011. Meningkatkan Kemampuan Koneksi Matematik dengan Menggunakan Pendekatan Konstruktivisme. Tesis SPS UPI Bandung: tidak diterbitkan

Malasari, P. N., Nindiasari, H., \& Jaenuddin. 2017. A development of Mathematical Connecting Ability of Students in Junior High School through a Problem-Based Learning with Course Review Horay Method. In Journal of Physics: Conference Series (Vol. 812, No.1, p. 012025). IOP Publishing.

Mullis, et,al. 2000. Timms 1999. Internastional report. Boston: the international study center, boston college, lynch school of education

NCTM. 2000. Handbook of research on mathematics teaching and learrning, editor: Douglas A. Grows USA: Macmilan Library Reference

Pannen, P. 2001. Konstrutivisme Dalam Pembelajaran. Jakarta : PAU-PPAI Universitas Terbuka

Plomp, T. 1997. Educational and Training System Design. Nederlands: University of Twente Faculty of Educational Science and Technology

Polya, G. 1973. How to Solve ( $\left.2^{\text {nd }} E d\right)$. Princeton University Press

Posamentier, A.S dan Stepelman, J. 1990. Teaching Secondary School Mathematics, Tecniques and Enrichment Units, 3th edition. Ohio: Merrill Publishing Company Columbus.

Ritonga. D, Sinaga, B \& Siagian, P. 2018. Diffrences in Mathematics Connection and Conseptual Understanding Ability between Students Taught by Using Problem Based Learning and Direct Learning Model in SMP Negeri 1 Bilah Barat. Journal of Education and Practice, Vol 9, No. 9. ISSN 2222-1735

Roger, R. 1990. The 19 Habits of Highky Successful People: Powerful Strategis for personal Triumph. Malaysia: Wynwood

Russefendi, E.T. 1991. Pengantar Kepada Membantu Guru Mengembangkan Kompetensinya dalam Pengajaran Matematika untuk Meningkatkan CBSA. Bandung: Tarsito

Ruspiani. 2000. Kemampuan Siswa dalam Melakukan Koneksi Matematis. Tesis SPS UPI Bandung: tidak diterbitkan

Shadiq, F. 2008. Pentingnya Pemecahan Masalah

Shunck, D.H, \& B.J Zimmerman. 2011. Handbook of Self-Regulated of Learning and Performance.Routledge. NewYork and London

Sinaga, B. 1999. Efektivitas Pembelajaran Berdasarkan Masalah (Problem Based Instruction) pada Kelas I SMU dengan Bahan Kajian Fungsi Kuadrat. Jurnal Penelitian Bidang Pendidikan

2007. Pengembangan Model pembelajaran matematika Berdasarkan Masalah Berbasis Budaya Batak (PBMB3). Disertasi Tidak dipublikasikan. Surabaya: PPs Universitas Negeri Surabaya.

Siregar, ND \& Surya, E (2017). Analysis of Students' High School Mathematikal Connection Ability. International Journal Of Sciences Basic and Applied Research.ISSN 2307-4531 Vol. 33, No. 2, pp 309-320.

Thiagarajan, S. Semmel, D.S. Semmel, M. 1974. Instructional Development for Training Teachers of Exceptional Children. A Sourse Book. Blomington: Central for Innovation on Teaching The Handicapped

Trianto, 2011. Mendesain Model Pembelajaran Inovatif-Progresif: Konsep, Landasan dan Implementasinya 
pada Kurikulum Tingkat Satuan Pendidikan (KTSP). Jakarta: Kencana.

Undang-undang Nomor 14 Tahun 2005 Tentang Guru Dan Dosen. Jakarta: Presiden Republik Indonesia

University of Southrn California. 2001. Problem Based learning

Wijaya, A. 2012. Pendidikan Matematika Realistik: Suatu Alternatif Pendekatan Pembelajaran Matematika. Yogyakarta: Graha Ilmu.

Yamin,M. 2013. Strategi dan metode dalam model Pembelajaran. Jakarta: GP Press Group. 